\title{
First experiences with direct drilling in Germany
}

\section{K. Baeumer}

Faculty of Agriculture, University of Göttingen, Germany

Recieved: 6 August 1970

\section{Summary}

The published results of trials in which conventional tillage methods have been compared with direct drilling, i.e. crop production with minimum possible tillage, are reviewed. Observed yield depressions were mainly caused by failure of seeding techniques and weed control. It is concluded that experiences gained so far do not justify the recommendation to use this system in general practice.

\section{Introduction}

Tillage systems in which mechanical soil manipulation is reduced to traffic and seedbed preparation only, are known as minimum and zero tillage or else as direct drilling systems. Sowing with as little mechanical preparation as possible presupposes chemical control of weed and suitable methods for seeding into consolidated soils. Both became available some years ago. Stimulated by successful trials abroad, investigations into direct drilling systems have been started in Germany during 1966. Since the experience of four years experimentation is not sufficient to evaluate this new system, first results, some problems and prospects of direct drilling can be discussed only.

\section{Motivation of direct drilling}

Soils are tilled to provide conditions suitable not only for optimum plant growth but also for necessary field operations, e.g. planting and harvesting. To achieve this a deep primary cultivation like ploughing, which loosens and inverts the soil, is considered to be the best basic operation. It facilitates weed control, burial of crop residues and seed-bed preparation. But neither the possibility for ploughing nor the advantage of a deep cultivation are always given.

An alternative to the traditional tillage system is most urgently needed, where timing of tillage operations is too difficult, performance insufficient and requirements of energy and labour too high. That is the case on very heavy or shallow and stony soils, which are really marginal for arable farming under the present economic conditions. As there are large districts in Germany where people have no other means for making their living than to farm such soils, about half of the existing trials with direct drilling is situated on marginal soils (Debruck, 1969, Czeratzki et al., 1969; Kahnt, 1969; Bachthaler, 1970).

But on easier workable soils too, direct drilling could be of interest. Apart from reducing costs for tillage operations, direct drilling may eventually alleviate some of the negative side-effects of tillage and repeated heavy traffic. 
On medium to heavy soils and during a wet season, tillage and traction can result in formation of soil pans. When caused by deep cultivations these pans are difficult to remove. They restrict the continuity of large, fast-draining soil pores. Consequently, the capacity of the soil for water infiltration, gas exchange, crop growth and trafficability is reduced. Without repeated deep cultivations, shrinking of clay particles and activity of soil organisms will eventually rebuild a system of continuous pores. It is thought that direct drilling finally results in a sod-like soil structure as frequently found under a cover of permanent grass. This soil structure should provide optimum conditions for both plant growth and the necessary traffic on the fields.

Bare soils are subject to soil erosion. Since ploughing removes every protecting cover and promotes mineralization of organic matter, fine sand or silt can be transported more easily by water and wind. The opinion is that some thrash left on the soil surface after direct drilling will stimulate aggregate stability and minimize soil erosion.

So in arable farming with short-living crops, regeneration of the soil to a stable sodlike structure is a motivation for omitting deep cultivation. In a ley-farming system direct drilling should preserve the accumulated organic matter during the period of arable cropping.

To study these problems, some of the existing trials with direct drilling are situated on easily tilled soils such as light or silt loams (Kahnt, 1969; Debruck, 1969; Czeratzki et al., 1969; Baeumer, 1970).

On soils without erosion or structural problems, purely economic reasons motivate direct drilling, not as a permanent system but to be used now and then as a single operation. Such possibilities have been studied by Teuteberg (1969) and Birnkammer (1970).

\section{Methods of direct drilling}

In the experiments reported the following methods of direct drilling have been used:

1. ST: spraying, triple-disc drilling

2. SR: spraying, rotaseeder drilling

3. SS : spraying, semavator drilling.

Chemical control of weed is a prerequisite of direct drilling. Therefore sowing operations usually start with spraying of suitable herbicides.

The sowing method is critical for establishing a satisfactory stand. One type of the triple-disc-seeder used is mounted on the tractor 3-point-linkage (method ST). This machine cuts a narrow slot into which the seed is placed, it therefore causes the least soil disturbance of all existing direct drilling equipments. Yet seeds are left uncovered and sowing depth can not be controlled. So drilling performance of this seeder is sometimes poor. Therefore Bakermans et al. (1968) fitted a trailing type with a fourth mulching disc to cover the seed and attached some special devices to ensure equal sowing depths.

Methods 2 and 3 are intended to minimize the risk of establishing an adequate stand. To achieve this a seed-bed is prepared by rotavating the soil to $3-8 \mathrm{~cm}$ depth. Of course this tillage operation will disturb soil structure more than Method 1. The rotaseeder type loosens only a strip in front of the seed coulters. The semavator type cultivates the total soil surface. The seed is drilled either into the loose soil or broadcasted during the rotavating action. In this case again the depth of sowing is uncontrolled, which can result in poor stands. 


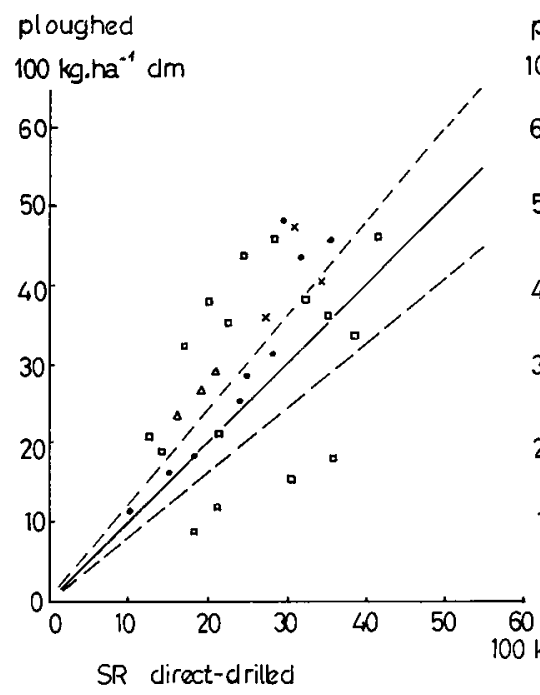

ploughed

$100 \mathrm{~kg} \cdot \mathrm{ha}^{-4} \mathrm{dm}$

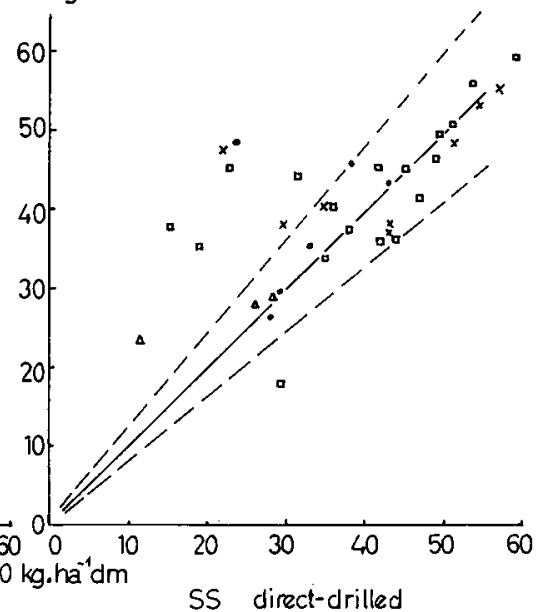

Fig. 1 Dry matter yield of direct-drilled and conventionally sown crops. For drilling methods see text: 'Methods of direct drilling'. (Sources: Bachthaler, 1970; Czeratzki et al., 1969; Debruck, 1969; Kahnt, 1969; Teuteberg, 1969; Baeumer et al., unpublished data.)

- Yields of crops produced by the tillage systems.

-..- Yield increase or decrease of $20 \%$ by either tillage system.

For explanation of symbols, see Fig. 2 .

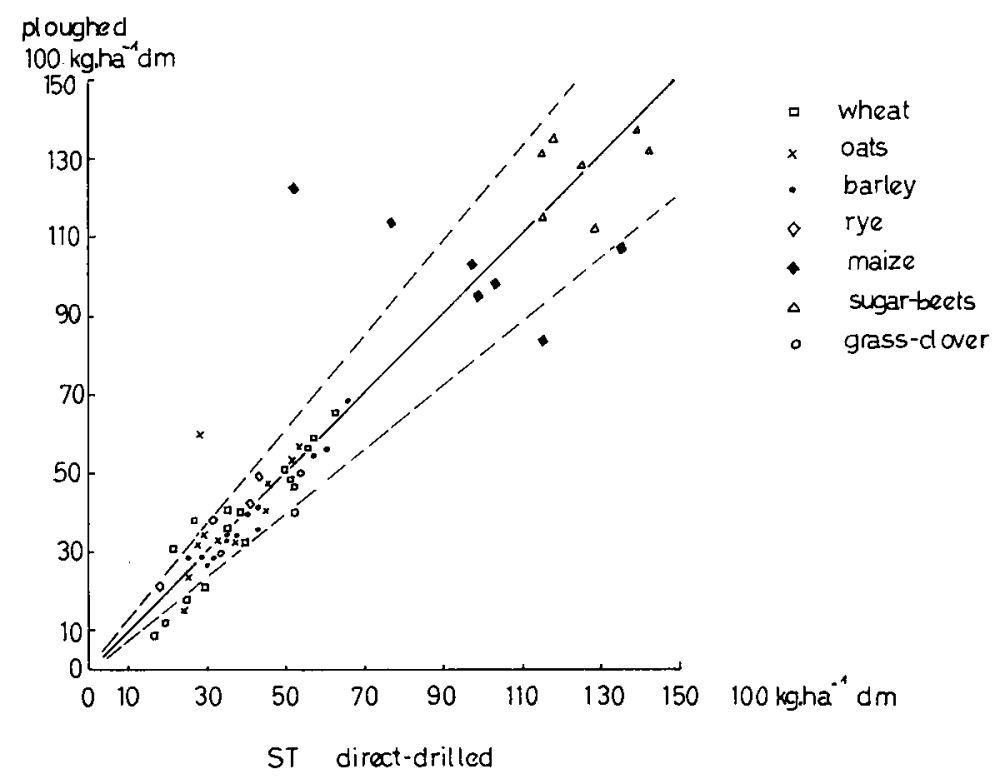

Fig. 2 See caption of Fig. 1.

Neth. J. agric. Sci. 18 (1970) 


\section{Results}

In Fig. 1 and 2 the available yield data of conventionally and directly drilled crops have been compiled. The graphs show that every method of direct drilling can occasionally effect substantial yield increments. But in most cases, direct drilling failed to give equal or higher yields than conventional tillage practices. Therefore, the possible causes for the observed yield depressions have to be examined.

\section{Stand density}

Kahnt $(1969,1970)$ reported the results of 3 trials with direct drilling at the Ihinger Hof near Stuttgart during 1967-1969. He examined the performance of wheat, barley, oats and field-beans on a silt loam (parabraunerde derived from loess, gray brown podzolic soil), on a clay loam (pelosol) and on a shallow calcareous soil (rendzina). Direct drilling was done by the SR and the SS method. Mean stand density and yield of the 3 cereal crops are shown in Table 1.

Both plant density and yield were strongly depressed by direct drilling, especially on soils with higher clay content (rendzina, pelosol). Differences between direct drilling methods were inconsistent over years and soils. The report states that in most cases direct drilling had caused reduced seedling emergence, though spring cereals had been direct-drilled with higher seed rates.

Debruck (1969) made the same experience. In his experiments during 1966-1968 at Rauisch-Holzhausen near Giessen (clay loam and silt loam, respectively) and at GrossGerau near Darmstadt (sand) he used the ST method without attached sod-mulchers. On the clay loam, mean seedling density was reduced by $20 \%$ as compared with conventional drilling. On the sand and the loam soil in some years seedling emergence was increased, in other years only slightly reduced. Drilling into a straw mulch resulted in more than $30 \%$ reduction of seedling emergence.

From these observations the conclusion can be drawn that inadequate performance of the direct drilling equipment used in these trials is one of the main causes for the failure of directly drilled crops. The shortcomings became obvious especially on soils with little tilth and during dry spells of the season.

After three years' experimentation with several direct drilling machines Kahnt (1970) summarized his experiences and evaluated the three direct drilling methods with regard to their capability to secure a full stand.

Triple-disc drilling (ST) failed:

1. when maize or field-beans were drilled;

Table 1 Influence of direct drilling on cereal yield and stand density at Ihingerhof (means of wheat, barley and oats during 1967-68; relative values. Source: Kahnt, 1969)

\begin{tabular}{|c|c|c|c|c|c|c|}
\hline \multirow{3}{*}{$\begin{array}{l}\text { Tillage } \\
\text { method }\end{array}$} & \multicolumn{6}{|c|}{ Soils } \\
\hline & \multicolumn{2}{|c|}{ parabraunerde } & \multicolumn{2}{|c|}{ rendzina } & \multicolumn{2}{|c|}{ pelosol } \\
\hline & stand & yield & stand & yield & stand & yield \\
\hline Ploughing & 100 & 100 & 100 & 100 & 100 & 100 \\
\hline Direct drilling & & & & & & \\
\hline SR & 86 & 85 & 51 & 54 & 67 & 76 \\
\hline SS & 78 & 76 & 79 & 69 & 49 & 67 \\
\hline
\end{tabular}


2. when used on dry or consolidated soils;

3. when used on leys with insufficient kill of the grass.

Rotaseeder drilling (SR) failed:

1. when rotavated strips were smaller than $3 \mathrm{~cm}$;

2. when drilling was done at high speed;

3. when used on wet, consolidated or uneven soil surfaces.

Semavator drilling (SS) did not produce satisfactory stands:

1. when used on wet or stony soils;

2. when small seeds were broadcasted.

Kahnt states finally that rotaseeder drilling with attached disc-seeders is the safest method to secure satisfactory stands. He did not examine a triple-disc drill with attached sod-mulchers and press-wheels as developed by Bakermans et al. (1968).

According to our own experience this improved type of sod-seeder is suitable for many soil conditions and produces stand densities comparable to conventional drilling methods. Unsatisfactory performance has been observed only when a thick layer of straw covered the soil surface.

\section{Weed control}

Some of the observed yield depressions were due to heavy weed infestations. In all trials reported, paraquat or diquat were used on directly drilled plots. Both herbicides inactivate above-ground plant parts, but do not kill completely perennial weeds like Convolvulus arvensis, Taraxacum officinale and Elytrigia repens. Since broad-leaved weeds are effectively controlled by the usual application of selective herbicides, gramineous weeds as Avena fatua and Elytrigia repens are strongly selected by repeated application of paraquat. This happened to be the case in all reported trials in which bipyridylium-salts have been used as the only total herbicides.

A typical example is shown in Table 2 with data reported by Schwerdtle (1970). He

Table 2 Influence of direct drilling on weed infestation and wheat yield at Ihingerhof (Source: Schwerdtle, 1970)

\begin{tabular}{|c|c|c|c|c|c|}
\hline \multirow{2}{*}{$\begin{array}{l}\text { Tillage } \\
\text { method }\end{array}$} & \multirow[t]{2}{*}{ Crop } & \multirow[t]{2}{*}{ Year } & \multirow{2}{*}{$\begin{array}{c}\text { Yield } \\
(100 \mathrm{~kg} \cdot \mathrm{ha}-1)\end{array}$} & \multicolumn{2}{|c|}{ Weed infestation $(g \cdot m-2)$} \\
\hline & & & & $\begin{array}{l}\text { dicotyl. } \\
\text { weeds }\end{array}$ & $\begin{array}{l}\text { Elytrigia } \\
\text { repens }\end{array}$ \\
\hline \multicolumn{6}{|l|}{ ploughed } \\
\hline & w. wheat & 1966 & 28.7 & 77 & 9 \\
\hline & w. wheat & 1967 & 38.1 & 143 & 59 \\
\hline & w. wheat & 1968 & 25.9 & 64 & 8 \\
\hline & maize & 1969 & 34.1 & 一 & - \\
\hline \multicolumn{6}{|l|}{ direct-drilled } \\
\hline & w. wheat & 1966 & 28.3 & 50 & 42 \\
\hline & w. wheat & 1967 & 35.2 & 133 & 119 \\
\hline & w. wheat & 1968 & 19.5 & 81 & 216 \\
\hline & maize & 1969 & 34.8 & - & - \\
\hline & w. wheat & 1966 & 32.1 & 76 & 87 \\
\hline \multirow[t]{3}{*}{ ST } & w. wheat & 1967 & 10.6 & 114 & 624 \\
\hline & w. wheat & 1968 & 2.5 & 50 & 3226 \\
\hline & maize & 1969 & 34.4 & - & - \\
\hline
\end{tabular}

\footnotetext{
* Fresh weight.
} 
iried to control couch-grass on directly drilled plots by applying high doses of TCA $\left(80 \mathrm{~kg} . \mathrm{ha}^{-1}\right)$ after the harvest of wheat. The following maize crop had been treated with atrazine at a rate of $3 \mathrm{~kg}$. ha-1. The combined action of the herbicides and the strong competition of the maize crop suppressed the couch-grass, but did not kill it completely.

Better results may be achieved if dalapon or aminotriazol are applied in combination with paraquat at a time when the couch-grass is still vigorously growing. Organic oil additives make small doses of these herbicides effective, so that a cruciferous crop can be grown a week or two after spraying.

The available information about couch-grass infestation of the existing direct drilling experiments suggests that several trials have to be discontinued unless the problem of couch-grass control is solved.

\section{Nutrient supply}

Omitting deep primary cultivation may result in reduced availability of plant nutrients, especially of nitrogen. If crop growth or yield are taken as the only indicator, a reduced nitrogen supply to direct drilled crops can be proved only in such situations where neither insufficient plant density nor heavy weed infestation interfere with normal crop growth. Most of the reported results are not free from such implications.

Debruck (1969) examined the effect of green manure, straw mulch and fertilizer nitrogen on the yield of direct-drilled cereal crops (Fig. 3 and 4). In 1967 and 1968 substantial yield depressions occurred on those direct-drilled plots, where the straw of the previous crop had been mulched (Fig. 3). These yield losses were caused mainly by a $30 \%$ reduction of plant density. Additional nitrogen supply eventually compensated this reduction, so that the yield of the direct-drilled crops equalled or surpassed those of the conventionally sown crops.

A different case is demonstrated in Fig. 4. On a clay soil nitrogen restricted cereal
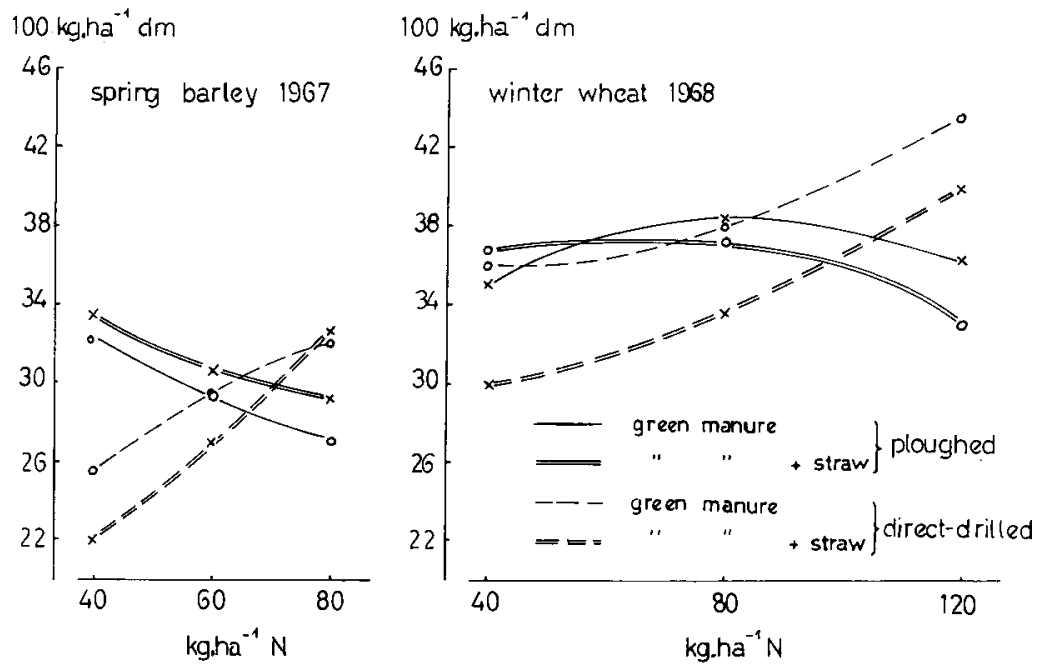

Fig. 3 Influence of tillage system, N-fertilization and type of mulch on yield of cereals at RauischHolzhausen (silt loam) 1967/68. (Source: Debruck, 1969.) 

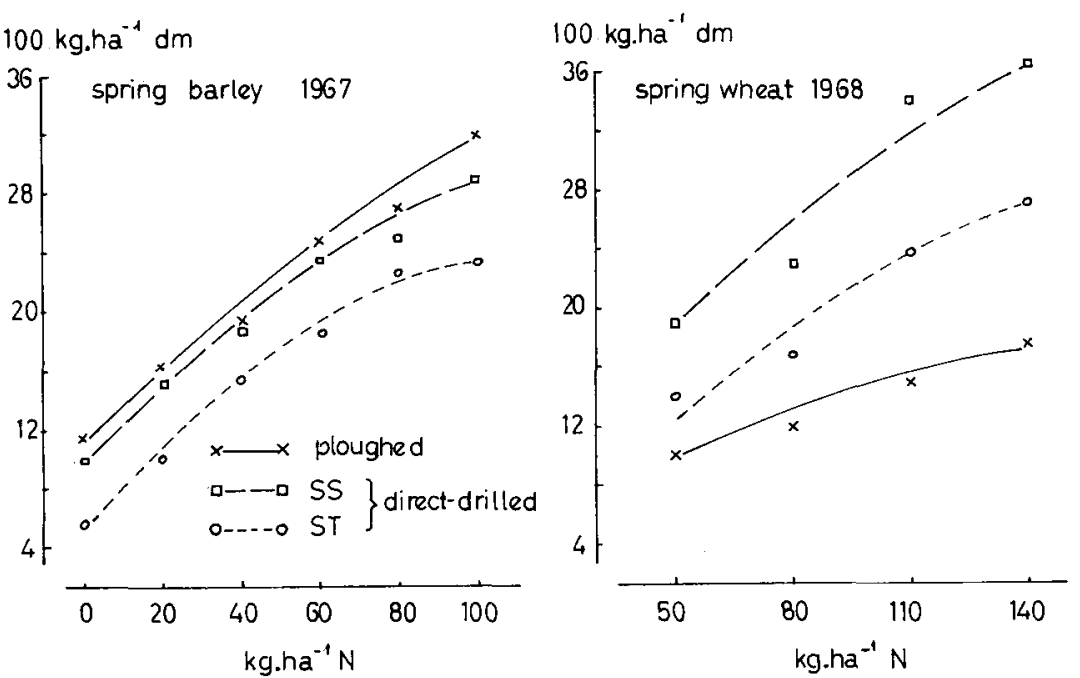

Fig. 4 Influence of tillage system and $N$-fertilization on dry matter yield of cereals at RauischHolzhausen (clay loam) 1967/68. (Source: Debruck, 1969.)

yield independently of the used tillage system. But there was a significant interaction between the effect of tillage systems and years or crops respectively. In 1967 the nitrogen application was less effective on direct-drilled soils, in 1968 on ploughed soils. Teuteberg (1969) reported similar observations. In his 12 experiments with directdrilled cereal crops in Schleswig-Holstein nitrogen application had been varied between 0 and $160 \mathrm{~kg} \cdot \mathrm{ha}^{-1}$. To judge wether nitrogen is less available in direct-drilled soils, the yield of plots without nitrogen fertilization are of special interest. Here in 6 out of 12 cases direct drilling resulted in higher yields. Since no comment is given of other factors interfering with normal crop production, it can be assumed that the availability of nitrogen was the main cause for the observed yield differences.

As stated above, grain yield is a questionable basis to judge wether nitrogen supply may become effective as growth restricting factor in direct drilling systems. A better source of information are differences between nitrogen yields of direct-drilled and conventionally sown crops. Table 3 contains some data observed in an experiment conducted on a silt loam at Göttingen (Pape, unpublished data).

Winter wheat and sugar-beets produced higher nitrogen yields on ploughed soil than on direct-drilled soil, though dry matter yields were very similar and did not increase by additional nitrogen application. From these data it may be concluded that nitrogen nutrition did not restrict production, but that nitrogen supply were different in both tillage systems. Again there was one exception. With low nitrogen doses the directdrilled barley crop produced a higher nitrogen yield than the conventionally sown crop. These results indicate that a generalizing statement about the availability of nitrogen in direct-drilled soils is not possible on the basis of the existing information. The frequently stated opinion that direct-drilled crops require more nitrogen to produce yields equal to conventionally sown crops, seems to be justified only when failure of crop establishment or some other restricting factors have to be compensated.

Potash and phosphorus may become growth-limiting factors too. Yet no information is available that this was the case in the reported experiments. 
Table 3 Influence of nitrogen fertilization on total dry matter production and nitrogen yield of direct drilled crop at Göttingen 1969 (Source: Pape, unpublished data)

\begin{tabular}{|c|c|c|c|c|}
\hline \multirow{3}{*}{$\begin{array}{l}\text { Crop } \\
\quad \text { tillage system }\end{array}$} & \multicolumn{4}{|c|}{ Nitrogen fertilization } \\
\hline & \multicolumn{2}{|c|}{$65 \mathrm{~kg} \cdot \mathrm{ha}-1$} & \multicolumn{2}{|c|}{$130 \mathrm{~kg} \cdot \mathrm{ha}=1$} \\
\hline & $D M(k g \cdot h a-1)$ & $N(k g \cdot h a-1)$ & $D M(k g \cdot h a-1)$ & $N(k g . h a-1)$ \\
\hline \multicolumn{5}{|l|}{ Wheat } \\
\hline ploughing & 12270 & 131 & 12070 & 133 \\
\hline direct drilling & 12250 & 117 & 12100 & 127 \\
\hline \multirow{5}{*}{$\begin{array}{l}\text { W. barley } \\
\text { ploughing } \\
\text { direct drilling }\end{array}$} & & & & \\
\hline & 7320 & 93 & 7390 & 105 \\
\hline & 7860 & 101 & 7780 & 104 \\
\hline & \multicolumn{4}{|c|}{ Nitrogen fertilization } \\
\hline & \multicolumn{2}{|c|}{$130 \mathrm{~kg} \cdot \mathrm{ha}-1$} & \multicolumn{2}{|c|}{$230 \mathrm{~kg} \cdot \mathrm{ha}=1$} \\
\hline \multicolumn{5}{|l|}{ Sugar-beets } \\
\hline ploughing & 21090 & 315 & 20560 & 357 \\
\hline direct drilling & 21170 & 265 & 20920 & 343 \\
\hline
\end{tabular}

\section{Soil structure}

Czeratzki et al. (1969), Kahnt (1969) and Bachthaler (1970) reported data about total and air-filled pore space on differently tilled soils. On direct-drilled plots they observed a reduction of the total pore space ranging from $1-7 \%(\mathrm{v} / \mathrm{v})$, so that minimum values of about $44 \%$ on a silt loam, $39 \%$ on a clay loam and $37 \%$ on a sandy soil were attained. Differences between ploughed and direct-drilled soils were mainly due to the reduction of large pores, which at field capacity are filled with air. The minimum values of these fast-draining pores have been reported with about $4 \%(\mathrm{v} / \mathrm{v})$ on soils with a high clay content. The question arises wether this pore space limits water infiltration or plant growth.

Fig. 5 shows the results of a case-study (Ehlers, unpublished data) on a silt loam cropped with wheat at Göttingen. In May 1970 the total pore space of the ploughed and direct-drilled plots had been measured as 49.9 and $43.2 \%(\mathrm{v} / \mathrm{v})$, respectively. The volume of pores $>60 \mu \mathrm{m}$ (equivalent diameter) were 17.5 and $8.7 \%$, respectively. After a period of drought most of the available soil water had been extracted by the wheat plants. The dotted lines in Fig. 5 show that the direct-drilled soil contained less water than the ploughed one. During 4 days at the end of June several rainstorms delivered $49 \mathrm{~mm}$ of precipitation. The continuous lines in Fig. 5 show that on the direct-drilled plots the infiltration front had reached a greater depth than on ploughed plots. As calculated from the difference between the water content at 26 June and 30 June, at least $45 \mathrm{~mm}$ had infiltrated the direct-drilled soil and $35 \mathrm{~mm}$ the ploughed one.

These results seem to contradict the pore space measurements. Though the volume of the draining pores was greater, the ploughed soil absorbed less water than the directdrilled soil. Therefore it may be concluded that the total volume of the draining pores is less important than their continuity, which on hte direct-drilled soil seems to be more effective. 

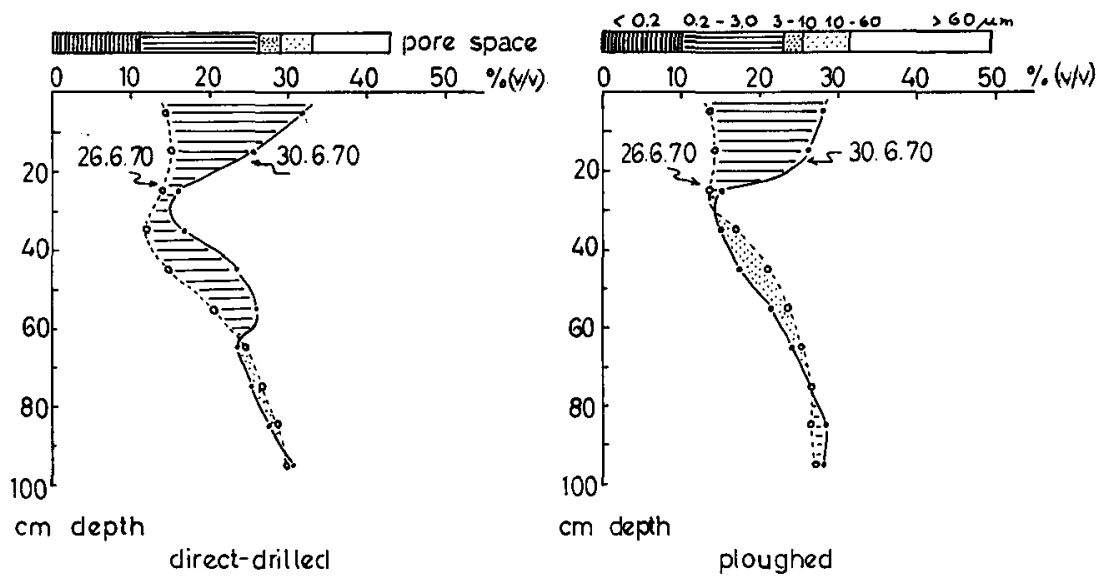

Fig. 5 Pore space and water infiltration on a direct-drilled and ploughed soil at Göttingen (silt loam). Dotted lines: water content in $\%(v / v)$ at 26 June 1970 ; continuous lines: water content at 30 June 1970. (Source: Ehlers, unpublished data.)

Judged by the yield of weed-free crops (Table 3), the soil structure of the unploughed soils did not become a critical factor for plant growth at Göttingen. Yet very little is known about this relationship. On a silt clay loam cropped with sugar-beets in 1970, recompaction of the ploughed soil by wheel tracks reduced total pore space to $36.5 \%$ $(v / v)$. Consequently the young beet plants exhibited stunted growth. On the directdrilled plot, where the same total pore space had been measured, the plants showed normal growth. The difference in soil structure, which in this case affected plant growth, needs further investigation.

No information about the trafficability of direct-drilled soils is given by the quoted authors. Occasional observations at Göttingen suggest, that trafficability is improved by direct drilling.

\section{Conclusions}

Reviewing the published results of the first 4-years experimentation with direct drilling systems, one gets the impression, that drilling technique and weed control are the main problems which have to be solved yet. Where prime interest is in using this new tillage system on marginal soils, it may be advisable to circumvent the difficulties mentioned. On soils with high structural stability, i.e. with a high clay content, rotavating the total soil surface and seeding with a triple-disc-coulter may lessen the risk of stand establishment. But on a silt loam the semavator drilling system would prevent the rebuilding of a soil structure which eventually could become more resistant to soil erosion.

For marginal soils Bachthaler (1970) proposed a mixed system of conventional and minimum tillage, i.e. a deep primary cultivation every 3-5 year. He considered this deep cultivation necessary to restore soil structure and to get phosphate and potash fertilizers into deeper soil layers. Since no information is available wether the altered soil structure or the accumulation of fertilizer nutrients in surface layers of direct- 
drilled soils really restrict plant growth, Bachthaler's argument seems to be unfounded. More likely the proposed deep tillage operation could be used to faciliate couch-grass control, if necessary.

After all, experiences gained so far with direct drilling systems in Germany do not justify the recommendation to introduce this system into general practice, even with the strongest motivations for omitting the normal deep cultivation. At present direct drilling is primarily a tool for the experimentator and scientist who is interested in ecological systems and intends to study the influence of tillage on plant growth. Here this new system has enlarged the scope of possibilities for further research.

\section{Aknowledgments}

The author is indebted to W. Ehlers and G. Pape for supplying some unpublished data.

\section{References}

Bachthaler, G., 1970. Die Stellung zur Direktsaat und die Minimalbodenbearbeitung in der Fruchtfolge. Merck Bl., Beitr. PflSchutz 20:36-42.

Baeumer, K., 1970. Die Standortfaktoren Boden und Klima bei pflugloser Bestellung. Merck Bl., Beitr. PflSchutz 20: 26-34.

Bakermans, W. A. P. \& L. ten Holte, 1968. Triple disc seeder in photographs. Mimeograph. rep., Inst. v. Biol. en Scheik. Onderzoek van Landbouwgewassen.

Birnkammer, H., 1970. Betriebswirtschaftliche Erfahrung bei der pfluglosen Umwandlung von Grünland in Ackerland. Merck Bl., Beitr. PflSchutz 20: 55-63.

Czeratzki, W., 1970. Möglichkeiten und Grenzen für den Einsatz pflugloser Bestellungsverfahren. Merck Bl., Beitr. PflSchutz 20: 18-25.

Czeratzki, W. \& E. Ruhm, 1969. Zweijährige Ergebnisse aus Versuchen zur bearbeitungslosen Bestellung. Ber. III. Int. Kongr. Techn. Landw., Sekt. II : 1-3, 7-12.

Debruck, I., 1969. Minimalbodenbearbeitung und Direktsaat. Mitt. dt. LandwGes. 84: $233-236$.

Herzog, R. \& O. Bosse, 1969. Direktsaat ohne Grundbodenbearbeitung. Feldwirtschaft 10: 373-374.

Kahnt, G., 1970. Technische Möglichkeiten für pfluglose Bestellung. Merck Bl., Beitr. PflSchutz 20: 3-8.

Kahnt, G., 1969. Ergebnisse zweijähriger Direktsaatversuche auf drei Bodentypen. Z. Acker- u. PflBau 129: 277-295.

Schwerdtle, F., 1970. Das Unkrautproblem bei pfluglosen Bestellungsmethoden. Merck Bl., Beitr. PflSchutz 20: 46-54.

Teuteberg, W., 1969. Pfluglose Ackerkultur. Landw. Forsch., Sonderheft 23/2: 133-139. 